\title{
Tribute to Olalekan Alabi Oduntan
}

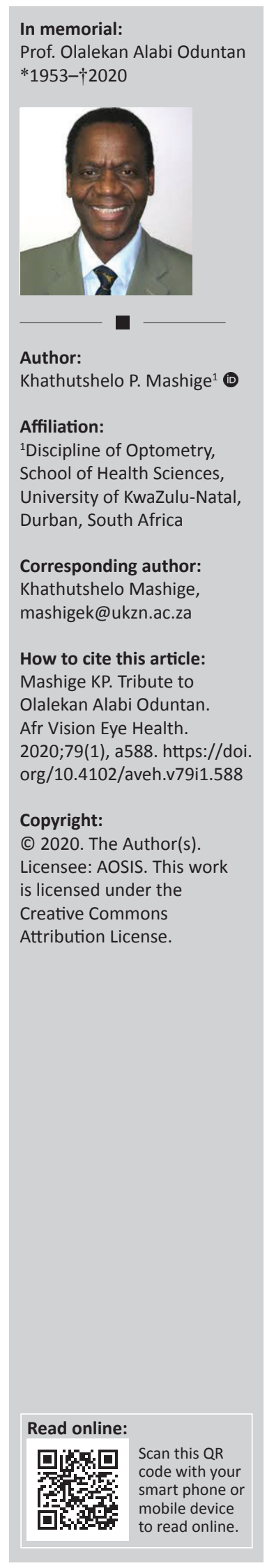

It is with great sadness that we inform you of the untimely passing of our dear colleague and friend Professor Olalekan Alabi Oduntan, better known as Prof. Ola, who passed away on 20 March 2020. His sudden passing is a loss to the world of optometry, particularly in Africa.

Professor Oduntan obtained a B.Sc. (First Class Hons) from the Department of Optometry, University of Benin, Nigeria, in 1982 and a PhD (Optometry) from the City University, London, United Kingdom, in 1989. He was a Commonwealth Scholar. He was appointed as Assistant Professor, King Saud University, Saudi Arabia (1989-1996); Associate Professor, University of Limpopo, South Africa (1996-2001); Professor, University of Limpopo, South Africa (2002-2008); Professor, University of KwaZulu-Natal, South Africa (2008-2013); and Honorary Professor, University of KwaZulu-Natal, South Africa (2014-present). He was the Head of the Department of Optometry, Madona University, Nigeria.

His major research achievements include the discovery of an elastic tissue layer in the primate conjunctiva (J. Anat. 1989, 163: 165-172); ${ }^{1}$ description of the source of sensory innervation of the inferior conjunctiva (Graefe's Arch. Ophthalmol. 1992, 230: 258-263); ${ }^{2}$ and report on the causes and prevalence of low vision and blindness in the Limpopo Province, South Africa (S. Afr Optom. 2003, 62: 8-15). ${ }^{3}$ He is the author of a monograph: Global visual impairment: Epidemiology, implications and prevention, University of Limpopo Press, 2005 (ISBN 0-9584778-8-4) and a chapter in a book: The role of psychotherapy in the contemporary rehabilitation of visually impaired patients. In: Madu NS (editor), Mental Health and Psychology in Africa. World Council for Psychotherapy, African Chapter, University of Limpopo Publisher, Polokwane, 2005. He has completed a book manuscript: Contemporary low vision care. He has supervised several $\mathrm{PhD}$ and master students. Professor Oduntan has published many articles in national and international journals. He was a C-rated scientist by the National Research Foundation.

Professor Oduntan was loving and real. He was a wonderful father to his three children and a loving husband to his wife. Although death is a part of life, once it strikes someone you so dearly love, your existence will never be the same. To Prof. Oduntan's family, I know the pain of losing your dad will perhaps never leave you, but I imagine it will ease with time as you process and get through it.

Professor Oduntan will always be remembered for his gentle nature and kind-heartedness, as well as the great support he offered to colleagues. He was a great mentor, always helpful and friendly to both staff and students and blessed with the most welcoming smile. He was a true professional. My hope is that he rests in eternal peace knowing he will always be in our hearts.

Issued by Professor Khathutshelo Percy Mashige.

\section{References}

1. Oduntan AO, Ruskell GL. A sub-epithelial elastic laminar in the palpebral conjunctiva of monkeys. J Anat. 1989;163:165-172.

2. Oduntan AO, Ruskell GL. The source of sensory fibres of the inferior conjunctiva of monkeys. Graefes Arch. Ophthalmol. 1992;230: 258-263. https://doi.org/10.1007/BF00176301

3. Oduntan AO, Nthangeni ME, Ramudzuli R, Madu SN. Causes and prevalence of low vision and blindness in the Limpopo Province of South Africa. S Afr Optom. 2003;62:8-15 | Afr Vision Eye Health. 2005;64(2), a214. https://doi.org/10.4102/aveh.v64i2.214 